\title{
Genetic diversity and species richness patterns in Baetidae (Ephemeroptera) in the Montseny Mountain range (North-East Iberian Peninsula)
}

\author{
Múrria, Cesc ${ }^{1, *}$, Morante, Maria ${ }^{1,2}$, Rieradevall, Maria ${ }^{1,3}$, Ribera, Carles $^{3,4}$ and Prat, Narcís ${ }^{1}$ \\ ${ }^{1}$ Grup de Recerca Freshwater Ecology and Management (FEM), Departament d'Ecologia, Facultat de Biologia, \\ Universitat de Barcelona (UB), Diagonal 643, 08028 Barcelona, Catalonia/Spain. \\ ${ }^{2}$ Departament de Farmacologia, Terapèutica i Toxicologia, Facultat de Veterinària, Edifici V, Universitat \\ Autonòma de Barcelona (UAB), 08193 Bellaterra, Catalonia/Spain. \\ ${ }^{3}$ Institut de Recerca de Biodiversitat (IRBio), Universitat de Barcelona (UB), Diagonal 643, 08028 Barcelona, \\ Catalonia/Spain. \\ ${ }^{4}$ Departament de Biologia Animal, Facultat de Biologia, Universitat de Barcelona (UB), Diagonal 643, 08028 \\ Barcelona, Catalonia/Spain.
}

*Corresponding author: francesc.murria@usherbrooke.ca

Received: 28/01/2014 Accepted: 08/08/2014

\begin{abstract}
Genetic diversity and species richness patterns in Baetidae (Ephemeroptera) in the Montseny Mountain range (NorthEast Iberian Peninsula)

This study aimed to describe patterns of diversity of Baetidae (Ephemeroptera) at the community and population levels within the Montseny Mountain range (North-East Iberian Peninsula). We studied both the distribution of 4 species of baetids in 20 sites among three catchments along the altitudinal gradient (350-1700 masl); and the genetic diversity of the mtDNA cytochrome c oxidase subunit I (coxl) gene of the two common species Baetis alpinus and Baetis rhodani. We found a gradual replacement of the dominant species along the altitudinal gradient. Baetis alpinus inhabited sites at high-altitudes, and this species was replaced by B. rhodani when the altitude decreased. Baetis melanonyx and Alainites muticus attained low abundance at all river sections, and no clear altitudinal trend appeared. Our hypothesis at the population level was that genetic structuring is associated with geographic distance and limited by drainage boundaries among the three studied catchments because of the short-time dispersion of adults. Unexpectedly, analyses of molecular variance (AMOVA) and isolation-bydistance (IBD) showed genetic diversity was unstructured by distance for both species, which may be explained by the relatively short spatial scale studied and small topographic barriers among the three catchments. The Generalized Mixed Yule-Coalescent (GMYC) model showed that B. rhodani had two differentiated genetic lineages that co-occurred in all sites. Overall, diversity of baetids was structured at the community level along the altitudinal gradient, whereas it was unstructured at the population level within the Montseny Mountain range.
\end{abstract}

Key words: Aquatic insects, cryptic species complex, genetic diversity, GMYC model, morphospecies, species assemblage, stream ecology.

\section{RESUMEN}

Diversidad genética y patrones de riqueza de especies de los Baetidae (Ephemeroptera) en la montaña del Montseny (NordEste de la Península Ibérica)

Este estudio pretende describir los patrones de diversidad de las especies (tanto a nivel de comunidad como de población) de los Baetidae (Ephemeroptera) presentes en la montaña del Montseny (Noreste de la Península Ibérica). Se estudiaron conjuntamente la distribución de 4 morfoespecies de baétidos en 20 puntos de muestreo en tres cuencas a lo largo del gradiente altitudinal (350-1700 msnm) y la diversidad genética del gen mitocondrial Citocromo Oxidasa Subunidad I (cox1) de las dos especies comunes B. alpinus $y$ B. rhodani. Se encontró una sustitución gradual de las morfoespecies dominantes a lo largo del gradiente altitudinal, B. alpinus se localizó en puntos de muestreo de mayor altitud y fue reemplazada por B. rhodani en puntos de muestreo de menor altitud. Baetis melanonyx y Alainites muticus se encontraron con baja 
abundancia a lo largo de todo el gradiente altitudinal y no apareció ningún patrón claro. Nuestra hipótesis a nivel de población era una estructuración genética asociada a la distancia geográfica y limitada por las montañas entre las tres cuencas estudiadas debido al efímero vuelo de los adultos. Sorprendentemente, los análisis genéticos de varianza molecular (AMOVA) y aislamiento por distancia (IBD) mostraron que la diversidad genética no estaba estructurada por la distancia en ninguna de las dos especies, y esto podría ser explicado por la escala espacial pequeña del trabajo y la poca altitud de las barreras topográficas entre las tres cuencas. El modelo Generalized Mixed Yule-Coalescent (GMYC) mostró que B. rhodani tenía dos linajes genéticos diferenciados que coexistían en todos los puntos de muestreo. En conjunto, la diversidad de baétidos a nivel de comunidad estaba estructurada a lo largo del gradiente altitudinal, mientras que no se encontró ninguna estructura a nivel de población en la montaña del Montseny.

Palabras clave: Insectos acuáticos, complejos de especies crípticas, diversidad genética, modelo GMYC, morfoespecies, ensamblaje de especies, ecología de ríos.

\section{INTRODUCTION}

Studies on the diversity patterns of freshwater macroinvertebrates at both community and genetic levels and at multiple spatial scales have contributed greatly to our understanding of the distribution and structure of freshwater diversity. One of the most important factors that determine freshwater diversity is the spatial hierarchical organisation of streams (Frissell et al., 1986), which has structured diversity at multiple temporal scales from species diversification to population genetic structure (Múrria et al., 2013). At the regional scale, the dispersion of aquatic organisms seems to be limited by drainage boundaries, which reduces connectivity between riverine invertebrate communities, thereby increasing $\beta$-diversity among catchments (Malmqvist, 2002). Limited connectivity also leads to some degree of intraspecific genetic differentiation across catchments for most freshwater species (Hughes et al., 2009). The topographical barriers among catchments are higher in headwaters than in mid-order or lowland river sections, thus $\beta$ - and $\gamma$-diversity are reduced from higher to lower reaches of rivers at both the species and genetic levels (Finn et al., 2011; Múrria et al., 2013). At the catchment scale, the longitudinal gradient of physical, chemical, and biological parameters from headwaters to the river mouth along river zonation (i.e., discharge, temperature, sediments) have driven the aquatic species distribution (Van- note et al., 1980, Ward, 1998) and species diversification within lineages (Múrria et al., 2012). At the local scale, hydraulics and variable flow forces produce habitat differentiations (i.e., riffles versus pools) that have promoted ecological niche segregation among species, with each micro-habitat harbouring different species (Statzner et al., 1988; Statzner, 2008). Therefore, the spatial hierarchical organisation of streams constrains the evolutionary, demographic and ecological processes of freshwater organisms and contributes in varying degrees to determine diversity at the local scale and the links between the local diversity and the regional diversity pool (Ward \& Tockner, 2001; Clarke et al., 2008; Finn et al., 2011; Múrria et al., 2013).

Baetidae (Ephemeroptera) have a worldwide distribution and high species diversity. Their aquatic larvae are collector-gatherers and facultative scrapers, while short-life flying adults disperse and complete their life cycle outside the water (Merritt et al., 2008). The life cycle of larval "downstream" drift and adult "upstream" short-time flight is comparable for several species of baetids and occurs on a scale of approximately $2 \mathrm{~km}$ in each direction and is limited by the geographical distance to a streamscale (Monaghan et al., 2002). However, local conditions and wind intensity, frequency and direction may increase this distance (Monaghan et al., 2005a). Environmental gradients at the large spatial scale determine the distribution and geographical replacement of individual 
baetid species. For example, the widespread Baetis alpinus (Pictet, 1843) is adapted to high oxygen concentrations and low temperatures and is mainly distributed at high altitudes across Europe (Monaghan et al., 2002, Finn et al., 2013, Finn et al., 2014). In contrast, the widespread and abundant Baetis rhodani (Pictet, 1983) is more tolerant of warmer and low oxygen water and occurs in mid-order and lowlands throughout the West Paleartic area (Gattolliat \& Sartori, 2008).

The established patterns of species distribution of Baetidae may change, because molecular studies showed evidence of distinct genetic lineages within the already recognised morphological species. For example, DNA-based studies of $B$. rhodani showed a considerable amount of variation within the mtDNA gene cytochrome $\mathrm{c}$ oxidase subunit I (coxl) that clustered in several differentiated lineages across Europe (Williams et al., 2006, Lucentini et al., 2011). For instance, there are three widely distributed haplogroups across the British Islands and Europe (I, III, and
VII), whereas one haplogroup was restricted to distribution in Denmark-France-Italy (VI) and three haplogroups were only located in Switzerland-Italy (II, IV, and V) (Williams et al., 2006, Lucentini et al., 2011). Similarly, B. alpinus in the Iberian Peninsula (Finn et al., 2013; Finn et al., 2014) and B. vernus in Finland (Ståhls \& Savolainen, 2008) showed high genetic divergence, suggesting also the existence of cryptic molecular speciation. Nevertheless, little is known of the distribution patterns of such cryptic species (i.e., coexistence in a site or species replacement along gradients) and their evolutionary history (Williams et al., 2006; Lucentini et al., 2011).

Genetic studies of baetids at the population level showed variable results associated mainly with river zonation. For example, the genus Baetis showed weak genetic substructuring for mid-order and lowland species (Schmidt et al., 1995; Alp et al., 2012,). In contrast high-altitude species showed limited gene flow and genetic

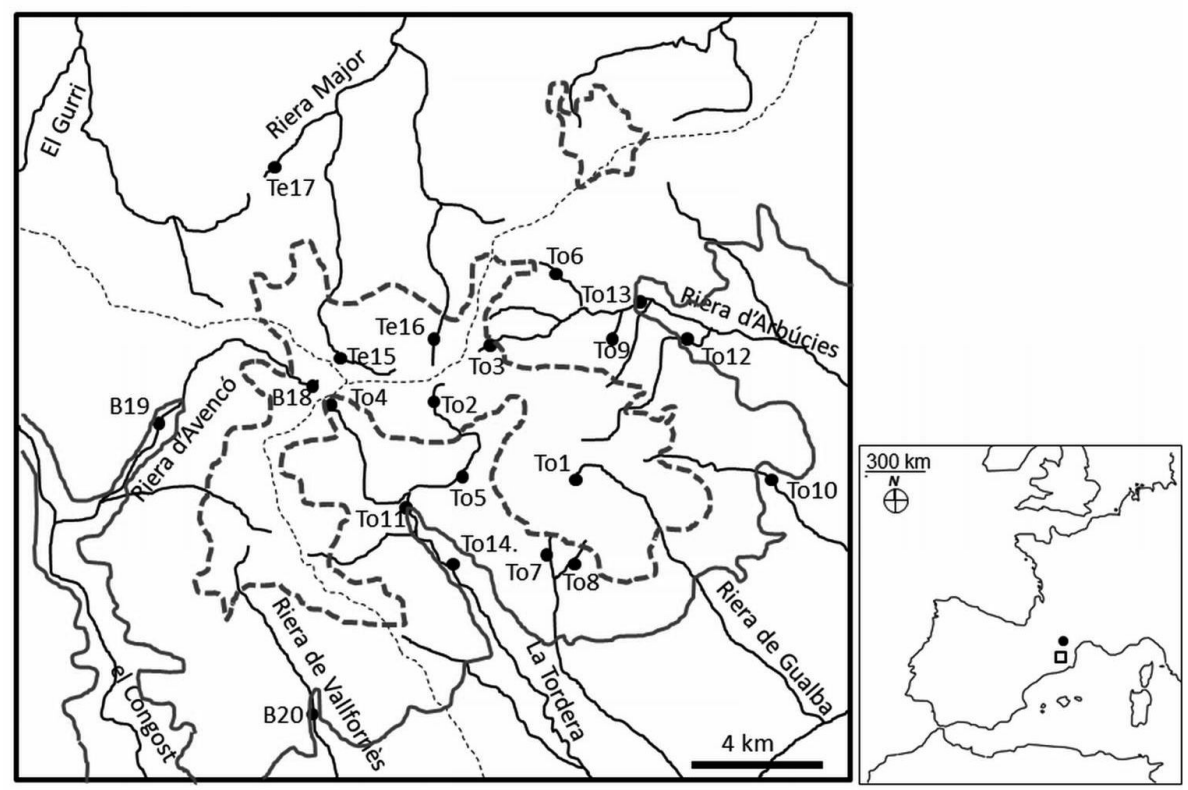

Figure 1. Location of the Montseny Mountain range (square) and sites sampled in Valira, Pyrenees (black dot) in western Europe. Geographical distribution of streams and rivers in the Montseny Mountain range, North-East Iberian Peninsula. Sampled sites are indicated by black circles. Fine dotted lines indicate drainage boundaries, the thick dotted line is an altitude of 1000 masl, and the thick line is an altitude of 500 masl. Localización de la montaña del Montseny Mountain (cuadro) y el punto de muestreo en el río Valira, Pirineos (punto negro) en el oeste de Europa. Distribución geográfica de los arroyos y ríos de la montaña del Montseny, Noreste de la Península Ibérica. Los puntos de muestreo están indicados con círculos negros. La línea de puntos gris indica los límites de cada cuenca, la línea de puntos gris es la topográfica de 1000 m. s.n.m., la línea continua gris es la topográfica de 500 m.s.n.m. 
diversity structured among adjacent valleys (Monaghan et al., 2002; Peckarsky et al., 2005; Finn et al., 2013). These contradictory results reveal the effects of the interacting factors determining genetic diversity, such as topographical barriers among and within catchments, the geographical scale of the study and differences in species traits.

Baetids represent an interesting group for biogeographical studies because of the short time of their adult stage and their limited ability to disperse. Our main objective was to describe the diversity patterns of baetids at both species and population levels within a single mountain range (Montseny, North-East Iberian Peninsula). For this reason, baetid species assemblages were assessed together with the genetic structure of cox 1 gene for two common species, the headwater $B$. alpinus and mid-order and lowland $B$. rhodani. We hypothesised a replacement of species along the altitudinal gradient due to the high altitudinal gradient within the Montseny Mountain range (350-1700 masl). At the population level, it is expected a higher gene flow among catchments for lowland species than for high-altitude species (Finn et al., 2011; Múrria et al., 2013). However, based on the small topographical barriers among headwater reaches, which are in close vicinity in this rounded mountain range, we expected a higher genetic structure for $B$. rhodani than $B$. alpinus. In addition, the genetic analysis may contribute to the assessment of the presence of differentiated genetic lineages within the studied species.

\section{MATERIALS AND METHODS}

\section{Study sites}

The Montseny Mountain range (North-East of the Iberian Peninsula) is located in the Mediterranean climate area $\left(2^{\circ} 16^{\prime}-2^{\circ} 33^{\prime} \mathrm{E}, 41^{\circ} 42^{\prime}-41^{\circ}\right.$ $\left.52^{\prime} \mathrm{N}\right)$ and shows an altitudinal gradient that ranges from 350 to 1700 masl within only a few kilometres. Streams of this mountain range flow into three main catchments discharging directly to the sea (Tordera, Besòs, and Ter). These catch- ments are characterised by different catchment area size, total discharge inside the Montseny Mountain range (Ter $>$ Besòs $>$ Tordera) and river flow seasonality with variable temporal patterns in the discharge regime (http://ecobill.diba. cat/, Fig. 1). In May and early June of 2007, baetid specimens were collected from 20 pristine localities distributed in a small area of $20 \mathrm{~km} \times 20 \mathrm{~km}$ throughout the three catchments, encompassing the entire range of environmental heterogeneity, geographic distribution and altitudinal gradient (Fig. 1, Table 1). The high altitude sites of the three catchments were in close vicinity, as shown Fig. 1, Table 1. Sites were grouped into three different altitudinal zone categories: high-altitude (>1000 m, 7 sites), mid-altitude (1000 m-500 m, 6 sites), and low-altitude $(<500 \mathrm{~m}, 7$ sites). The shortest aerial distance between sites was assigned on a map scale of 1:24000 (available at http://www.icc.cat). A few specimens of $B$. alpinus from the Valira del Nord stream, Pyrenees, Andorra (Fig. 1, Table 1), located $100 \mathrm{~km}$ north of the Montseny Mountain range, were sequenced to increase the genetic variability and resolution for running the species delimitation analysis.

\section{Morphological species identification}

Aquatic macroinvertebrates were collected from all in-stream habitats at each site using a kick net (250 $\mu \mathrm{m}$ mesh size) and similar kicking-effort between sites (approximately 30 minutes/site). The larvae of baetids were sorted in the field and directly preserved in absolute ethanol. In the laboratory, organic material of head capsules and abdomens were digested in $10 \%$ potassium hydroxide at $85^{\circ} \mathrm{C}$, rinsed in distilled water, and dehydrated in ethanol (successively $70 \%$ and $96 \%$ ). After digestion, each part was mounted on a slide with Euparal ${ }^{\mathrm{R}}$ solution to examine the mouthparts, legs, and abdomens with a light microscope. All individuals were identified at the taxonomic species level using several taxonomical keys (Müller-Liebenau, 1969; Belfiore, 1983; Puig, 1983a; Elliot et al., 1988). The thorax of each animal was preserved in absolute ethanol and kept frozen for molecular analysis. 


\section{Analysis of the structure of morphospecies assemblages}

The abundance of the four recorded species per site and similarity of species assemblages among sites were used to assess the structure of the species assemblages along the altitudinal gradient and geographical distance. First, the differences in species composition among the three altitudinal zone categories were examined. The differences among these categories were assessed by one-way Kruskal-Wallis tests due to the non-parametric distribution of the abundance of species. The similarity between species assemblages was measured by the Sørensen similarity index (Koleff et al., 2003). A Mantel test was conducted to separately test the decays of similarity of the species assemblages considering altitudinal differences and geographical distance among the sites. All statistical analyses were run using "vegan" (Oksanen et al., 2011) and "stats" libraries implemented in the R package (R Development Core Team, 2011).

\section{DNA extraction, amplification, and sequencing}

The DNA extraction of B. alpinus and B. rhodani was performed using standard phenol:chloroform protocol. Primers LCO-1490 and HCO-2198 (Folmer et al., 1994) were used to amplify a

Table 1. Stream, catchment, location and species composition of sites sampled in the Montseny Mountain range together with catchment and site location for the site located in Valira stream (Pyrenees, Andorra). Balp = Baetis alpinus; Brho = Baetis rhodani, Bmel = Baetis melanonyx $;$ Amut = Alainites muticus. Río, cuenca, localización y composición de especies de los puntos de muestreo en la montaña del Montseny, y cuenca y localización del punto de muestreo en el río Valira (Pirineos, Andorra).

\begin{tabular}{|c|c|c|c|c|c|c|c|c|c|c|c|}
\hline \multirow[b]{2}{*}{ Site } & \multirow[b]{2}{*}{ Site name } & \multirow[b]{2}{*}{ Catchment } & \multirow[b]{2}{*}{ Sub-catchment } & \multirow[b]{2}{*}{ X_UTM } & \multirow[b]{2}{*}{ Y_UTM } & \multirow[b]{2}{*}{ Altitude (m asl) } & \multicolumn{5}{|c|}{ Species composition } \\
\hline & & & & & & & Balp & Brho & Bmel & Amut & total \\
\hline To1 & Riera de Passavets & Tordera & Tordera & 454522 & 4625774 & 1206 & 4 & 0 & 6 & 0 & 10 \\
\hline To2 & Sant Marçal & Tordera & Tordera & 451891 & 4628243 & 1060 & 9 & 0 & 0 & 0 & 9 \\
\hline To3 & El Rigrós & Tordera & Riera d'Arbúcies & 451254 & 4628661 & 1055 & 59 & 0 & 0 & 1 & 60 \\
\hline To4 & Riera de la Bessa & Tordera & Tordera & 447666 & 4627303 & 1013 & 45 & 0 & 0 & 3 & 48 \\
\hline To5 & Tordera & Tordera & Tordera & 450869 & 4626238 & 733 & 4 & 10 & 2 & 0 & 16 \\
\hline To6 & Sot de Lliors & Tordera & Riera d'Arbúcies & 452364 & 4630590 & 715 & 5 & 3 & 0 & 7 & 15 \\
\hline To7 & Riera de Ciuret a & Tordera & Tordera & 452865 & 4622880 & 708 & 0 & 11 & 1 & 0 & 12 \\
\hline To8 & Riera de Ciuret b & Tordera & Tordera & 453396 & 4622657 & 696 & 7 & 3 & 0 & 7 & 17 \\
\hline To9 & Riera d'Arbúcies b & Tordera & Riera d'Arbúcies & 455195 & 4630228 & 550 & 6 & 16 & 7 & 0 & 29 \\
\hline To10 & Riera de Riells & Tordera & Riera d'Arbúcies & 459754 & 4625967 & 489 & 0 & 0 & 0 & 12 & 12 \\
\hline To11 & La Llavina & Tordera & Tordera & 448218 & 4624971 & 460 & 13 & 14 & 5 & 0 & 32 \\
\hline To12 & Riera de les Truites & Tordera & Riera d'Arbúcies & 457210 & 4629644 & 430 & 0 & 21 & 0 & 0 & 21 \\
\hline To13 & Riera d'Arbúcies a & Tordera & Riera d'Arbúcies & 455722 & 4630825 & 425 & 3 & 36 & 2 & 0 & 41 \\
\hline To14 & Piscines Montseny & Tordera & Tordera & 449246 & 4623563 & 397 & 0 & 16 & 0 & 0 & 16 \\
\hline Te15 & Torrent de Rentadors & Ter & Riera Major & 446684 & 4629051 & 1293 & 3 & 19 & 0 & 10 & 32 \\
\hline Te16 & Torrent de Collpregon & Ter & Riera Major & 449564 & 4629282 & 1242 & 7 & 0 & 0 & 0 & 7 \\
\hline $\mathrm{Te} 17$ & Riera de l'Erola & Ter & Riera Major & 447278 & 4631967 & 800 & 0 & 53 & 0 & 0 & 53 \\
\hline B18 & Collformic & Besòs & Congost & 445899 & 4628321 & 1125 & 33 & 1 & 0 & 0 & 34 \\
\hline B19 & Riera de Vallcàrquera & Besòs & Congost & 440309 & 4625916 & 448 & 0 & 35 & 0 & 11 & 46 \\
\hline B20 & Riera de Cànoves & Besòs & Mogent & 448979 & 4617125 & 420 & 0 & 38 & 0 & 0 & 38 \\
\hline Valira & Andorra & Ebre & Valira del Nord & 532357 & 3712300 & 1802 & & & & & \\
\hline
\end{tabular}


fragment of the mtDNA gene coxl. When these primers failed for some individuals of $B$. rhodani, we used the primers C1-J-1718 and C1-N-2191 (Simon et al., 1994). The Polymerase Chain Reaction (PCR) was carried out in $25 \mu \mathrm{l}$ with $1 \mu \mathrm{l}$ of templated DNA; $1 \mu \mathrm{l}$ of dNTPs; $1 \mu \mathrm{l}$ of each primer $(10 \mu \mathrm{M}) ; 2 \mu \mathrm{l}$ of $\mathrm{MgCl}_{2}, 13.9 \mu \mathrm{l}$ of $\mathrm{ddH}_{2} \mathrm{O} ; 5 \mu \mathrm{l}$ of buffer; and $0.1 \mu \mathrm{l}$ of Taq Polymerasa. After 5 minutes at $94{ }^{\circ} \mathrm{C}$, the PCR mixture was subjected to 35 cycles of 1 minute at $42^{\circ} \mathrm{C}, 40$ seconds at $94^{\circ} \mathrm{C}$, and 1 minute at $72{ }^{\circ} \mathrm{C}$, followed by a final extension step of 5 minutes at $72{ }^{\circ} \mathrm{C}$. The PCR products were purified and sequenced using Big Dye v.3.1 Terminator technology (Applied Biosystems, Foster City, CA, USA) and an ABI 3730 automated sequencer (Applied Biosystems). The intraspecific variability of the coxl gene is commonly used to determine gene flow among populations and to infer evolutionary histories of species, despite the inherent limitations of the mitochondrial coxl gene in some genetic studies because the coxl is a single, maternally inherited, haplotype marker (Avise, 2009). In addition, coxl is the most used molecular marker in freshwater biology studies at the population level for assessing genetic structure (Pauls et al., 2014).

\section{Molecular species delimitation}

The Generalized Mixed Yule-Coalescent (GMYC) model (Fujisawa \& Barraclough, 2013) was used to distinguish differentiated genetic lineages within B. rhodani and B. alpinus based on molecular criteria. This model tested for a change in branching rates at the speciespopulation boundary and divided them into either inter-specific ("diversification") or intraspecific ("coalescent"). Each "diversification" branch was delimited and considered an "independently evolving" mtDNA cluster. The unique coxl haplotypes for an edited fragment of $578 \mathrm{bp}$ for B. alpinus and 469 bp for B. rhodani located in Montseny Mountain range plus one coxl sequences for each haplogroup in Williams et al. (2006) and the out-group B. vernus (see GenBank accession numbers in Fig. 4) were used to perform the GMYC analysis. A maximum like-

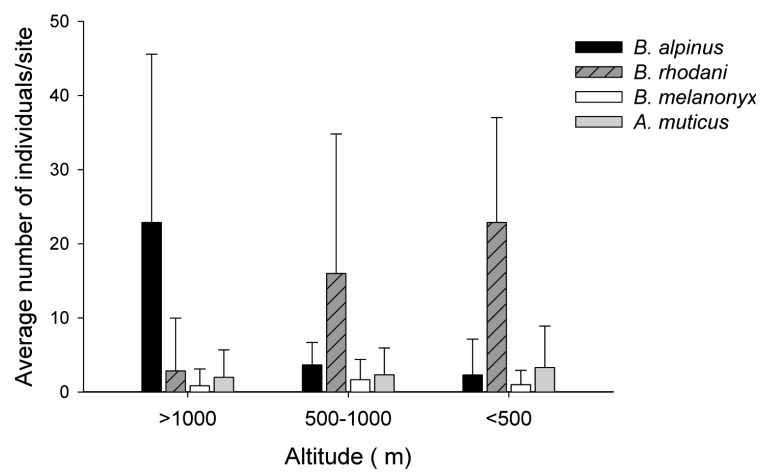

Figure 2. Mean and standard deviation of individuals per site for each morphological Baetidae species, grouped by three altitudinal categories: $>1000 \mathrm{~m}, 500 \mathrm{~m}-1000 \mathrm{~m}$, and $<500 \mathrm{~m}$. Media y desviación estándar del número de individuos por punto de muestreo para cada especie morfológica de baétidos agrupados en tres categorías de altitud: $>1000 \mathrm{~m}, 500-1000 \mathrm{~m}$ $y<500 \mathrm{~m}$.

lihood phylogeny was obtained with RAxML v.7.0.4 (Stamatakis, 2006) under a GTR $+\Gamma$ substitution model. The resulting topology was made ultrametric using the penalised likelihood as implemented in r8s v. 1.7 (Sanderson, 2003) with the optimal smoothing parameter selected by cross-validation. The GMYC analysis was conducted using the "Splits" package from the R package (Ezard et al., 2009) with the "single threshold" option. The resulting independent evolutionary entities were considered separately in the population genetic analysis. Pairwise genetic distance (\% of net nucleotide substitution per site) for haplogroups of $B$. rhodani was measured using DnaSP v5 (Librado \& Rozas, 2009).

\section{Analysis of intraspecific genetic structure}

The analysis of the population genetic structure to infer dispersion and gene flow among populations was carried out using only GMYC entities that had more than 5 individuals sequenced in average per population (Table 2). The genetic diversity for each GMYC entity was calculated by polymorphic sites and nucleotide diversity $\pi$ (i.e., the average number of nucleotide differences per site between two sequences) and its variance (Nei, 1987) using DnaSP v5 (Librado \& Rozas, 2009). In order to test genetic isolation-by-distance (IBD), genetic divergence 
$D_{x y}$ between populations (i.e., the average number of nucleotide substitutions per site between populations, Nei, 1987) and the geographical distances between populations were correlated by a Mantel test using the "vegan" library (Oksanen et al., 2011) implemented in the $\mathrm{R}$ package (R Development Core Team, 2011). The molecular variance (AMOVA) was used to assess the level of gene flow among populations and to test at what spatial scale genetic variability was structured. The AMOVA was carried out by estimating $\Phi_{S T}$ using 10000 random permutations and tested at three spatial hierarchic levels: among catchments; among populations in each catchment; and within populations. These analyses were conducted using ARLEQUIN v.3.5 (Excoffier et al., 2005).

\section{RESULTS}

A total of 548 individuals of Baetis and Alainites were collected from 20 localities belonging to four different morphospecies: B. rhodani $(276$ individuals); B. alpinus (198 individuals); $B$. melanonyx (Pictet, 1843) (23 individuals); and A. muticus (Waltz \& MacCafferty, 1994) (51 individuals) (Table 1). Baetis alpinus was mainly collected at high-altitude sites $\left(\chi^{2}=8.12\right.$, $p=0.02)$. Baetis rhodani became the predominant morphospecies at low-altitude sites $\left(\chi^{2}=7.94, p=0.02\right)$ (Fig. 2). Baetis melanonyx and $A$. muticus exhibited low abundance and were evenly distributed across altitude categories $\left(\chi^{2}=1.45, p=0.48\right.$ and $\chi^{2}=0.04, p=0.98$, respectively). All morphospecies were located

Table 2. Haplotype composition of the sampled sites for B. alpinus and B. rhodani haplogroup 1 (B. rhodanil) and haplogroup 2 (B. rhodani2). Sample size (Ind), number of individuals for each unique haplotype, and nucleotide diversity $(\pi)$ in each of the populations are indicated. Composición de los haplotipos de los sitios muestreados de B. alpinus y B. rhodani haplogrupo 1 (B. rhodani1) y haplogroup 2 (B. rhodani2). Se indica el tamaño de muestra (Ind), número de individuos para cada haplotipo único y diversidad nucleotidica $(\pi)$ en cada población.

\begin{tabular}{|c|c|c|c|c|}
\hline Species & site & Ind & Haplotypes (ind) & Nucleotide diversity $(\pi)$ \\
\hline \multirow[t]{7}{*}{ B. alpinus } & Te16 & 5 & $1(1), 2(4)$ & 0.00173 \\
\hline & B18 & 4 & $1(2), 2(2)$ & 0.00173 \\
\hline & To2 & 6 & $1(6)$ & - \\
\hline & To3 & 4 & $1(4)$ & - \\
\hline & To4 & 6 & $1(2), 2(4)$ & 0.00173 \\
\hline & Total & 25 & & $0.00173 \pm 0.00087$ \\
\hline & Valira & 9 & $1(2), 3(6), 4(1)$ & 0.00346 \\
\hline \multirow[t]{7}{*}{ B. rhodani 1} & $\mathrm{Te} 15$ & 5 & $1(3), 2(1), 4(1)$ & 0.00711 \\
\hline & Te17 & 10 & $1(2), 4(8)$ & 0.0064 \\
\hline & To11 & 6 & $1(3), 3(2), 4(1)$ & 0.00569 \\
\hline & To13 & 6 & $1(2), 4(3), 6(1)$ & 0.00995 \\
\hline & B19 & 7 & $1(2), 5(5)$ & 0.01279 \\
\hline & $\mathrm{B} 20$ & 6 & $3(1), 4(5)$ & 0.00213 \\
\hline & Total & 40 & & 0.00967 \\
\hline \multirow[t]{7}{*}{ B. rhodani 2} & Te15 & 3 & $7(3)$ & - \\
\hline & Te17 & 2 & $7(2)$ & - \\
\hline & To11 & 1 & $10(1)$ & - \\
\hline & To13 & 4 & $7(2), 8(1), 10(1)$ & 0.01421 \\
\hline & B19 & 2 & $9(1), 10(1)$ & 0.0064 \\
\hline & B20 & 1 & $7(1)$ & - \\
\hline & Total & 13 & & 0.01173 \\
\hline
\end{tabular}


in all catchments, except for B. melanonyx that was present only along the Tordera stream. The sampled sites were mono-specific (7 sites), di-specific (6 sites) or tri-specifics (7 sites), and no sites contained the four species. Species co-occurrence, irrespective to species identity, was common. The distance decay of similarity of morphospecies assemblages was significant when considering only altitudinal differences among the sites $(r=0.31, p<0.01)$, whereas it was decoupled along geographical distance ( $r=0.017, p=0.47$ ) (Fig. 3).

The 53 individuals sequenced for B. rhodani resulted in 10 unique coxl haplotypes (GenBank accession numbers KM098089-KM098098). The GMYC analysis clustered these haplotypes in two independent evolutionary lineages: haplogroup 1 and haplogroup 2 (likelihood of null model: -23.64, maximum likelihood of GMYC model: -15.24 , likelihood ratio test: $p=0.0008$ ) (Fig. 4). These two GMYC entities for the morphospecies $B$. rhodani had high genetic divergences between them $\left(D_{x y}=0.129\right.$ with a total 54 polymorphic sites) and co-occurred in all sites in the Montseny Mountain range. The 40 individuals sequenced from the morphospecies $B$. rhodani haplogroup 1 resulted in six unique haplotypes that differed in 10 segregating

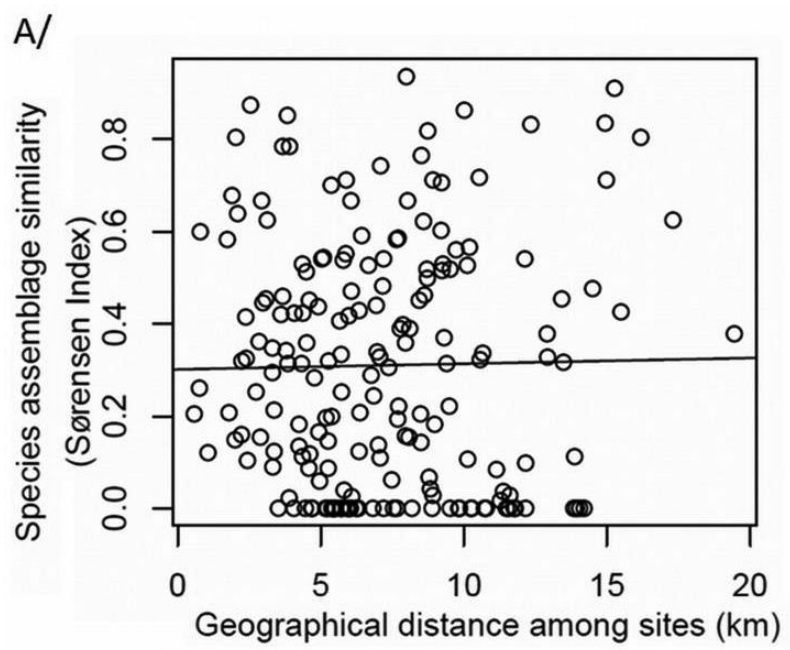

sites. The 13 individuals sequenced from the $B$. rhodani haplogroup 2 resulted in 4 unique haplotypes with 11 segregating sites. Sequences of the $B$. rhodani haplogroup 1 clustered with the haplogroup VII described by Williams et al. (2006), whereas sequences of $B$. rhodani haplogroup 2 clustered with haplogroup III. These two haplogroups were closely related in our phylogeny (Fig. 4). The 25 individuals sequenced for B. alpinus in the Montseny Mountain range resulted in two haplotypes and 1 segregating site. The 9 specimens from Valira resulted in 3 haplotypes, and one of these was also located in the Montseny Mountain range (GenBank accession numbers KM098085-KM098088). The GMYC analysis clustered together these four unique haplotypes. Table 2 shows haplotype composition and nucleotide diversity $(\pi)$ per site.

Baetis rhodani haplogroup 1 and $B$. alpinus showed similar intraspecific genetic structure characterised by significant differences within populations and among populations within a catchment and non-significant structure among the three catchments (Table 3). The IBD for both GMYC entities were non-significant (B. rhodani haplogroup 1: $r=0.25, p=0.26 ; B$. alpinus: $r=0.12, p=0.52$ ), indicating that each haplotype can be everywhere at the studied spatial scale.

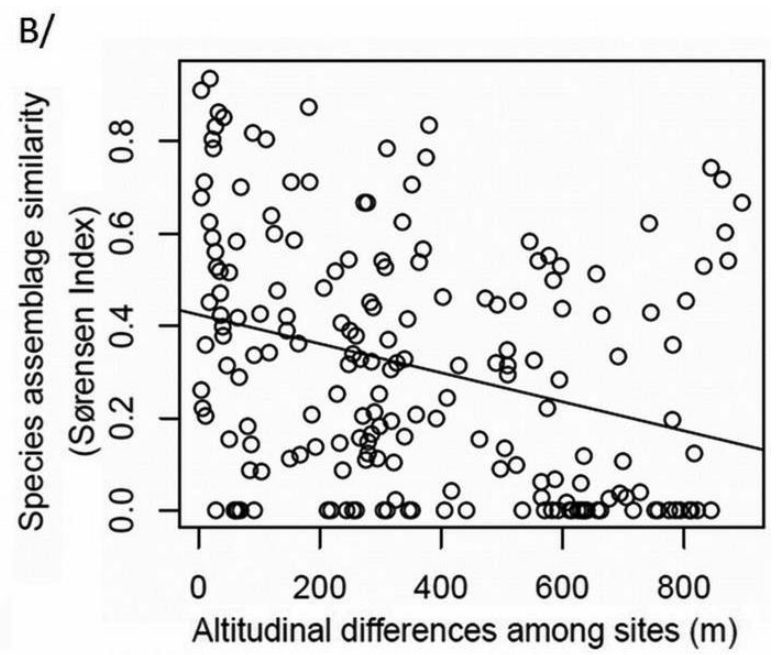

Figure 3. Distance decay of similarity (Sørensen index) for all pairwise comparisons of species assemblages of Baetis in the Montseny Mountain range plotted against (A) geographic distance (Mantel test, $r=0.017, p=0.47$ ) and (B) altitude difference (Mantel test, $r=0.31, p=0.001$ ). Decaimiento de la similitud (índice de Sørensen) de todos los pares de comparaciones de ensamblajes de especies del género Baetis en la montaña del Montseny con (A) la distancia geográfica (Mantel test, $\mathrm{r}=0.017$, $\mathrm{p}=0.47)$ y $(B)$ la diferencia de altitud (Mantel test, $\mathrm{r}=0.31, \mathrm{p}=0.001$ ). 


\section{DISCUSSION}

The distance decays of similarity of species assemblages of baetids in the Montseny Mountain range were higher along the altitudinal gradient than the geographical distance, which indicated the relevance of the altitude on patterns of species distribution. As expected, the dominant B. alpinus preferred reaches at the highest altitudes and gradually was replaced by $B$. rhodani along the altitudinal gradient. In contrast, the less abundant $B$. melanonyx and A. muticus had less habitat preferences along river sections, which suggested a more neutralgeographical based distribution than niche-based distribution for these two species. This result

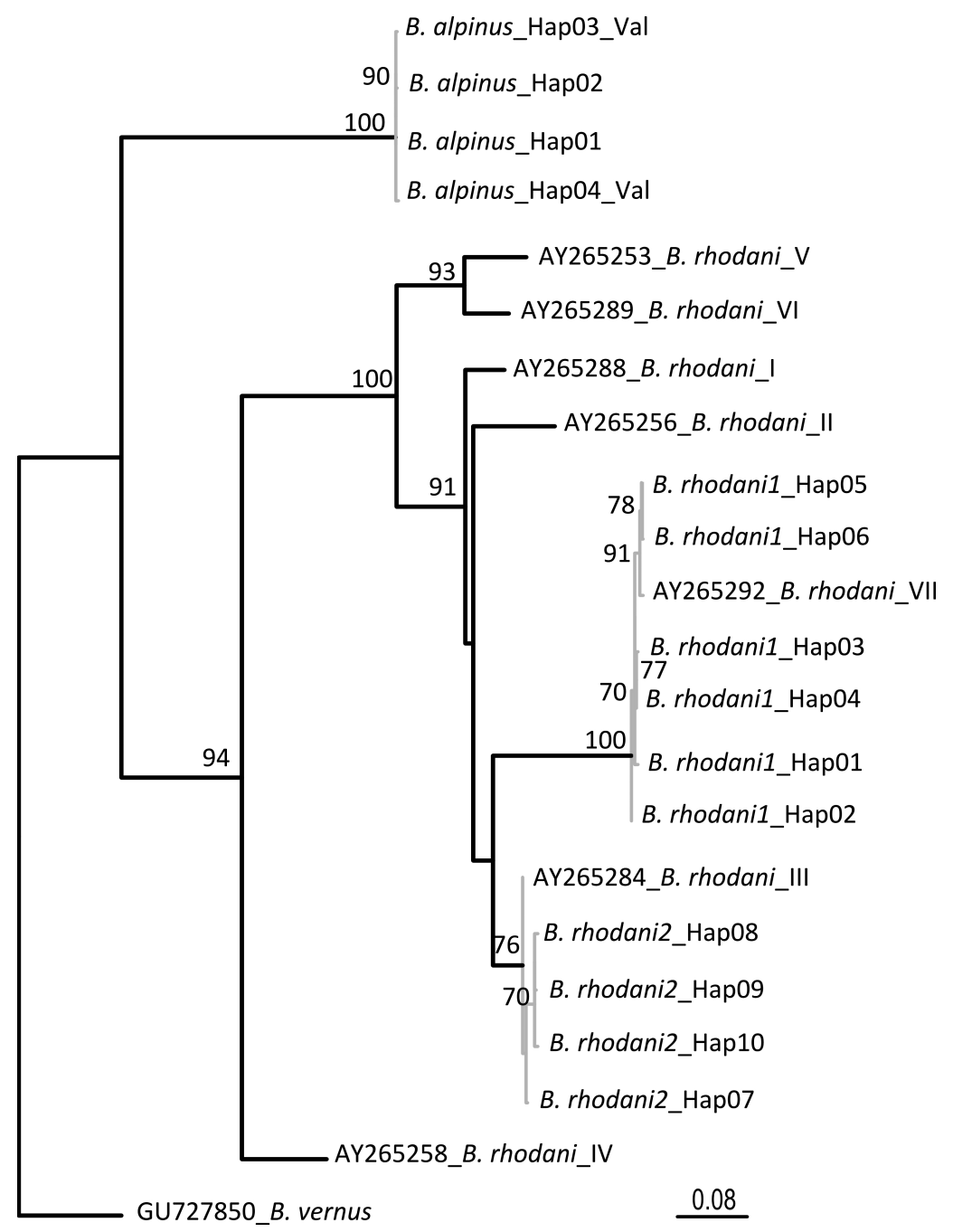

Figure 4. Phylogenetic relationship among B. alpinus and B. rhodani located in the Montseny Mountain range and Valira River, Pyrenees (Val) based on the Maximum Likelihood tree of unique coxl haplotypes. Baetis vernus was used as the out-group, and one coxl sequence for each B. rhodani haplogroup in Williams et al. (2006) was included (GenBank accession number indicated). Branch support is indicated as the maximum likelihood bootstrap $(>70)$. Gray phylogenetic clades are allocated to the coalescent by the GMYC model that corresponds to GMYC entities. Relación filogenética utilizando un árbol de máxima verosimilitud entre los haplotipos únicos del gen cox1 de B. alpinus y B. rhodani encontrados en la montaña del Montseny y el río Valira, Pirineos (Val). Además fueron usados B. vernus como grupo externo y una secuencia de cox 1 para cada grupo de haplotipos del trabajo de Williams et al. (2006). Se indica el suporte de cada rama del árbol con valores de bootstrap $>60$. En rojo se marcan los clados filogenéticos que fueron diferenciados por coalescencia por el modelo GMYC que corresponden a entidades GMYC. 
is not surprising because environmental factors related to altitudinal gradients (e.g., oxygen concentration, temperature, flow velocity) have driven species diversification of freshwater invertebrates ( Múrria et al., 2012) and are among the most influential factors affecting the distribution of freshwater macroinvertebrate communities, including baetids (Vannote et al., 1980;, AlbaTercedor, 1984; Puig, 1984b; Minshall, 1988; Alba-Tercedor et al., 1991; Monaghan et al., $2005 b$ ). The new contribution of this study to such well known patterns is the gradual replacement of the two dominant species and their co-occurrence in 8 of the 20 sampled sites, which discards a pattern caused by a clear border between their distributions as expected by habitat segregation (Ogitani et al., 2011). The weak decay of similarity of species assemblages along the geographical distance was unexpected because the geographical distance was an important factor for structuring freshwater communities (Astorga et al., 2012; Bonada et al., 2012) and is particularly relevant for baetids, given the short period of time aerial dispersion. However, the dispersion of the studied species seemed to exceed the geographical range of our study, hence individuals of $B$. melanonyx and $A$. muticus arrived and established in all streams within the Montseny Mountain range. Individuals of $B$. alpinus and $B$. rhodani can establish if they can pass the environmental filters related to altitude.

The GMYC model provided evidence of two independent evolutionary lineages within
B. rhodani for the gene coxl. These results confirmed the previous findings that morphology alone does not discover the true diversity hidden within B. rhodani characterised by a very distinct molecular differentiation (Williams et al., 2006; Lucentini et al., 2011). This prompts the need to reassess the morphological characters based on a neotype recently designed by Gattolliat \& Sartori (2008). The evolutionary history of this species complex is unknown, so the co-occurrence of two GMYC entities in all sites in the Montseny Mountain range provides valuable data for future studies. A study that assessed the evolutionary history of three coexisting cryptic species of B. rhodani found reinforced genetic differentiation by both phylogenetic over-dispersion (i.e., coexisting species had different ecological niches to reduce competitive exclusion) and the temporal turnover of adult emergence during a year (Lucentini et al., 2011). In contrast, our phylogeny indicated that the haplogroups III and VII were phylogenetically closely related. These two haplogroups are widely distributed across Europe. Haplogroup III was previously recorded in Norway, Sweden, Denmark, Switzerland, and the UK. Haplogroup VII was located in Denmark, Ireland, Germany, Spain, Switzerland, and the UK. Therefore, further work is needed to elucidate the evolutionary history of $B$. rhodani cryptic species complex based on ecological niches, temporal segregation at the local scale and the geographical distribution of each distinct genetic lineage.

Table 3. Results of the hierarchical analysis of molecular variance (AMOVA) of haplotype divergence $\left(\Phi_{S T}\right)$ for Baetis alpinus and Baetis rhodani haplotype $1 .{ }^{*} p<0.05$, $* p<0.001$. Resultados del análisis jerárquico de la varianza molecular (AMOVA) de la divergencia de los haplotipos $\left(\Phi_{\mathrm{ST}}\right)$ para Baetis alpinus y Baetis rhodani haplotipo 1. $* \mathrm{p}<0.05$, * $* 0.001$.

\begin{tabular}{lcccc}
\hline B. alpinus & d.f. & Variance components & Percentage variation & Fixation indexs \\
\hline Among catchments & 2 & -0.02 & -9.25 & $F_{C T}=-0.09$ \\
Among populations within catchments & 2 & 0.13 & 49.31 & $F_{S C}=0.45^{*}$ \\
Within populations & 20 & 0.15 & 59.94 & $F_{S T}=0.4^{*}$ \\
\hline B. rhodanil & d.f. & Variance components & Percentage variation & Fixation indexs \\
\hline Among catchments & 2 & -0.12 & -8.54 & $F_{C T}=-0.08$ \\
Among populations within catchments & 3 & 0.55 & 39.7 & $F_{S C}=0.36^{*}$ \\
Within populations & 35 & 0.95 & 68.84 & $F_{S T}=0.31^{* *}$ \\
\hline
\end{tabular}


The intraspecific genetic structure indicated that adults of $B$. alpinus and $B$. rhodani dispersed across drainage boundaries within the Montseny Mountain range and most likely their dispersion exceeded the studied spatial scale. However, individual dispersion was limited and each species was restricted by altitude. For the headwater B. alpinus, the detected gene flow among the catchments may be explained by the short aerial distances between sites (max. distance $4 \mathrm{Km}$ ) and also by the low-altitude of the drainage boundaries. Similarly, connectivity among the midstream and lowland sites may explain the high gene flow detected for $B$. rhodani. This result was partially in contradiction with the expected patterns of higher dispersal limitation by topographic barriers for high-altitude than mid- and low-altitude species (Finn et al., 2011; Múrria et al., 2013). However, the small spatial scale of our study and the geographical distribution of catchments in very close proximity to one another, with the absence of a predominant wind direction, can explain the detected pattern. Other population genetic studies of baetids found the genetic structure within and among populations in a catchment were unrelated to the geographical distance (Schmidt et al., 1995; Bunn \& Hughes, 1997; Monaghan et al., 2002; Peckarsky et al., 2005). This finding is in agreement with the patterns observed in the present study. This pattern was attributed to "patchy recruitment" when local populations were genetically stochastic as a result of few matings (Schmidt et al., 1995; Bunn \& Hughes, 1997).

In conclusion, results at the species and population levels revealed different portions of the patterns of baetid diversity within the Montseny Mountain range. The altitudinal gradient has driven the replacement of the morphospecies of baetids, whereas this gradient and the associated topographic barriers among catchments appeared to be unrelated to the genetic population structure. Moreover, the studied spatial scale may hide the general patterns of baetid diversity detectable at larger spatial scales. Differentiated genetic lineages within $B$. rhodani co-occurred at local sites, hence their distribution was unrelated to habitat segregation. Overall, the patterns at different organisational levels revealed different portions of the diversity, associating habitat heterogeneity and biological traits with intraspecific genetic structure, lineage diversification and the processes of species assembly.

\section{ACKNOWLEDGMENTS}

We thank J. Alba-Tercedor for helping with taxonomical identifications; M. Alp, R. Acosta, G. Pace and N. Bonada for comments on earlier versions of the manuscript; O. Marimón for assistance in the field; J. Roca for assistance in the molecular lab; and the F.E.M. research group members for helping in the field, especially N. Sánchez-Millaruelo, P. Fortuño, M. Cañedo-Argüelles and L. Puértolas. This work was supported in part by a Beatriu de Pinós postdoctoral fellowship (BP-DGR-2011) to CM by the Agència de Gestió d'Ajuts Universitaris i de Recerca, Generalitat de Catalunya.

\section{REFERENCES}

ALBA-TERCEDOR, J. 1984. Ecología, distribución y ciclos de desarrollo de efemerópteros de Sierra Nevada (Granada, España). II: Baetidae (Insecta, Ephemeroptera). Limnética, 1: 243-246.

ALBA-TERCEDOR, J., C. ZAMORA-MUÑOZ, A. SÁNCHEZ-ORTEGA \& I. GUISASOLA 1991. Mayflies and Stoneflies from the Río Monachil (Sierra Nevada, Spain) (Ephemeroptera and Plecoptera). In: Overview and Strategies of Ephemeroptera and Plecoptera. J. Alba-Tercedor \& A. Sánchez-Ortega (eds.): 529-538, The Sandhill Crane Press. FL. USA.

ALP, M., I. KELLER., A. M. WESTRAM \& C. T. ROBINSON. 2012. How river structure and biological traits influence gene flow: a population genetic study of two stream invertebrates with differing dispersal abilities. Freshwater Biology, 57: 969-981.

ASTORGA, A., J. OKSANEN, M. LUOTO J. SOININEN, R. VIRTANEN \& T. MUOTKA 2012. Distance decay similarity in freshwater communities: do macro- and microorganisms follow the 
same rules? Global Ecology and Biogeography, 21: 365-375.

AVISE, J. C. 2009. Phylogeography: retrospect and prospect. Journal of Biogeography, 36: 3-15.

BELFIORE, C. 1983. Efemerotteri (Ephemeroptera). Guide per il reconscimento dell specie animali delle aque interne italiane, Museo Civico di Storia Naturale de Verona. Verona. Italy.

BONADA, N., S. DOLÉDEC \& B. STATZNER. 2012. Spatial autocorrelation patterns of stream invertebrates: exogenous and endogenous factors. Journal of Biogeography, 39: 56-68.

BUNN, S. E. \& J. M. HUGHES. 1997. Dispersal and recruitment in streams: evidence from genetic studies. Journal of the North American Benthological Society, 16: 338-346.

CLARKE, A., R. M. NALLY, N. BOND \& P. S. LAKE. 2008. Macroinvertebrate diversity in headwater streams: a review. Freshwater Biology, 53: $1707-1721$.

ELLIOT, J. M., U. HUMPESCH \& T. MACAN. 1988. Larvae of the British Ephemeroptera. A key with ecological notes, Freshwater Biological Association scientific publication. London. UK.

EXCOFFIER, L., G. LAVAL \& S. SCHNEIDER. 2005. Arlequin ver. 3.0: an integrated software package for population genetics data analysis. Evolutionary Bioinformatics Online, 1: 47-50.

EZARD, T., FUJISAWA, T.\& BARRACLOUGH, T. G. 2009. Splits: SPecies' LImits by Threshold Statistics. R package version 1.0-11/r29. Available from http://R-Forge.R-project.org/projects/splits/.

FINN, D. S., N. BONADA, C. MÚRRIA \& J. M. HUGHES. 2011. Small but mighty: headwaters are vital to stream network biodiversity at two levels of organization Journal of North American Benthological Society, 30: 963-980.

FINN, D. S., K. KHAMIS \& A. M. MILNER. 2013. Loss of small glaciers will diminish beta diversity in Pyrenean streams at two levels of biological organization. Global Ecology and Biogeography, 22: 40-51.

FINN, D. S., C. ZAMORA-MUÑOZ, C. MÚRRIA, M. SÁINZ-BARIÁIN \& J. ALBA-TERCEDOR. 2014. Evidence from recently deglaciated mountain ranges that Baetis alpinus (Ephemeroptera) could lose significant genetic diversity as alpine glaciers disappear. Freshwater Science, 33: $207-$ 216.
FOLMER, O., M. BLACK, W. HOEH, R. LUTZ \& R. VRIJENHOEK. 1994. DNA primers for ampplification of mithocondrial cytocrome $\mathrm{C}$ oxidase subunit I from diverse metazoan invertebrates. Molecular Marine Biology and Biotechnology, 3: 294 299.

FRISSELL, C. A., W. J. LISS, C. E. WARREN \& M. D. HURLEY. 1986. A hierarchical framework for stream habitat classification: viewing streams in a watershed context. Environmental Management, 10: 199-214.

FUJISAWA, T. \& T. G. BARRACLOUGH. 2013. Delimiting Species Using Single-Locus Data and the Generalized Mixed Yule Coalescent. Approach: A Revised Method and Evaluation on Simulated Data Sets. Systematic Biology, 62: 707-724.

GATTOLLIAT, J. L. \& M. SARTORI. 2008. What is Baetis rhodani (Pictet, 1843) (Insecta, Ephemeroptera, Baetidae)? Designation of a neotype and redescription of the species from its original area. Zootaxa, 1957: 69-80.

HUGHES, J. M., D. T. SCHMIDT \& D. S. FINN. 2009. Genes in streams: using DNA to understand the movement of freshwater fauna and their riverine habitat. Bioscience, 59: 573-583.

KOLEFF, P., K., J. GASTON \& J. J. LENNON. 2003. Measuring beta diversity for presence-absence data. Journal of Animal Ecology, 72: 367-382.

LIBRADO, P. \& J. ROZAS. 2009. DnaSP v5: A software for comprehensive analysis of DNA polymorphism data. Bioinformatics, 25: 1451-1452.

LUCENTINI, L., M. REBORA, M. E. PULETTI et al. 2011. Geographical and seasonal evidence of cryptic diversity in the Baetis rhodani complex (Ephemeroptera, Baetidae) revealed by means of DNA taxonomy. Hydrobiologia, 673: 215-228.

MALMQVIST, B. 2002. Aquatic invertebrate in riverine landscapes. Freshwater Biology, 47: 679-694.

MERRITT, R. W., K. W. CUMMINS \& M. B. BERG. 2008. An introduction to aquatic insects of North America, Kendall/Hunt Publishing Company, Dubuque, IA. USA.

MINSHALL, G. W. 1988. Stream ecosystem theory: a global perspective. Journal of the North American Benthological Society, 7: 263-288.

MONAGHAN, M. T., P. SPAAK, C. T. ROBINSON \& J. V. WARD. 2002. Population genetics of 3 alpine stream insects: influences of gene flow, demographics, and habitat fragmentation. Journal of North American Benthological Society, 21: 114131. 
MONAGHAN, M. T., J. L. GATTOLLIAT, M. SARTORI et al. 2005a. Trans-oceanic and endemic origins of the small minnow mayflies (Ephemeroptera, Baetidae) of Madagascar. Proceedings of the Royal Society B: Biological Sciences, 272: 1829-2836.

MONAGHAN, M. T., C. T. ROBINSON, P. SPAAK \& J. V. WARD. 2005b. Macroinvertebrate diversity in fragmented Alpine streams: implications for freshwater conservation. Aquatic Science, 67: 454-464.

MÜLLER-LIEBENAU, I. 1969. Revision der europaischen arten der gattung Baetis Leach, 1815 (Insecta, Ephemeroptera). Gewässer und Abwässer, 48/49: 1-124.

MÚRRIA, C., N. BONADA, M. A. ARNEDO, C. ZAMORA-MUÑOZ, N. PRAT \& A. P. VOGLER. 2012. Phylogenetic and ecological structure of Mediterranean caddisfly communities at various spatio-temporal scales. Journal of Biogeography, 39: 1621-1632.

MÚRRIA, C., N. BONADA, M. A. ARNEDO, N. PRAT \& A. P. VOGLER. 2013. Higher $\beta$ and $\gamma$-diversity at species and genetic levels in headwaters than in mid-order streams in $\mathrm{Hy}$ dropsyche (Trichoptera). Freshwater Biology, 58: 2226-2236.

NEI, M. 1987. Molecular Evolutionary Genetics, Columbia University Press, New York. USA.

OGITANI, M., K. SEKINÉ \& K. TOJO. 2011. Habitat segregation and genetic relationship of two heptageniid mayflies, Epeorus latifolium and Epeorus l-nigrus, in the Shinano-gawa River basin. Limnology, 12: 117-125.

OKSANEN, J., F. G. BLANCHET, R. KINDT, P. LEGENDRE, P. R. MINCHIN, R. B. O'HARA, G. L. SIMPSON, P. SOLYMOS, M. H. H. STEVENS $\&$ H. WAGNER. 2011. Vegan: Community Ecology Package. $R$ package version 2.0-2. Available from: http://CRAN.R-project.org/package=vegan.

PAULS, S. U., M. ALP, M. BÁLINT, P. BERNABÒ, F. J. ČIAMPOR, Z. ČIAMPOROVÁ-ZAŤOVIČOVÁ, D. S. FINN, J. KOHOUT, F. LEESE, V. LENCIONI, I. PAZ-VINAS \& M. T. MONAGHAN. 2014. Integrating molecular tools into freshwater ecology: developments and opportunities. Freshwater Biology, 59: 1559-1576.

PECKARSKY, B. L., J. M. HUGHES, P. B. MATHER, M. HILLYER \& A. C. ENCALADA. 2005. Are population of mayflies living in adja- cent fish and fishless streams genetically differentiated? Freshwater Biology, 50: 42-51.

PUIG, M. À. 1984a. Efemerópteros y plecópteros de los ríos catalanes. Parte 3. Claves de géneros y espcies de efemerópteros. $\mathrm{Ph}$. D. Thesis. Universitat de Barcelona, Catalonia.

PUIG, M. À. 1984b. Distribution and ecology of the Baetidae in Catalonia rivers (NE-Spain). In: Proceedings IVth International Conference of Ephemeroptera. Landa V. et al. (eds.): 127-134, Czech Academy of Sciences Ed., Praga. Czech Republic. R DEVELOPMENT CORE TEAM. 2011. R: a language and environment for statistical computing. R Foundation for Statistical Computing, Vienna, Austria. Available at: http://www.R-project.org/

SANDERSON, M. J. 2003. r8s: Inferring absolute rates of molecular evolution and divergence times in the absence of a molecular clock. Bioinformatics, 19: 301-302.

SCHMIDT, S. K., J. M. HUGHES \& S. E. BUNN. 1995. Gene flow among conspecific population of Baetis sp. (Ephemeroptera): adult flight and larval drift. Journal of North American Benthological Society, 14: 147-157.

SIMON, C., F. FRATI, A. BECKENBACH, B. CRESPI, H. LIU \& P. FLOOK. 1994. Evolution, weighting and phylogenetic utility of mitochondrial gene sequences and compilation of conserved polymerase chain reactions primers. Annals of the Entomological Society of America, 87: 651-701.

STÅHLS, G. \& E. SAVOLAINEN. 2008. MtDNA COI barcodes revealed cryptic diversity in the Baetis vernus group (Ephemeroptera, Baetidae). Molecular Phylogenetics and Evolution, 46: 83-87.

STAMATAKIS, A. 2006. RAxML-VI-HPC: maximum likelihood-based phylogenetic analyses with thousands of taxa and mixed models. Bioinformatics, 22: 2688-2690.

STATZNER, B., J. A. GORE \& V. H. RESH. 1988. Hydraulic stream ecology: observed patterns and potential applications. Journal of North American Benthological Society, 7: 307-360.

STATZNER, B. 2008. How views about flow adaptation of benthic stream invertebrates changed over the past century. International Journal of Hydrobiology, 93: 593-605.

VANNOTE, R. L., G. W. MINSHALL, K. W. CUMMINS, J. R. SEDELL \& C. E. CUSHING. 1980. The river continuum concept. Canadian Journal of Fisheries and Aquatic Sciences, 37: 130-137. 
WARD, J. V. 1998. Riverine landscapes: biodiversity patterns, disturbance regimes, and aquatic conservation. Biological Conservation, 83: 269-278.

WARD, J. V. \& K. TOCKNER. 2001. Biodiversity: towards a unifying theme for river ecology. Freshwater Biology, 46: 807-819.
WILLIAMS, H. C., S. J. ORMEROD \& M. W. BRUFORD. 2006. Molecular systematics and phylogeography of the cryptic species complex Baetis rhodani (Ephemeroptera, Baetidae). Molecular Phylogenetics and Evolution, 40: 370-382. 